\title{
Anticommunism in popular culture: the evolution and contestation of "anticommunist films" in South Korea
}

Hana Lee®

\author{
Correspondence: \\ ihanalee@gmail.com \\ Senior Researcher, kyujanggak \\ Institute for Korean Studies, Seoul \\ National University, Seoul, Korea
}

\begin{abstract}
The goal of this paper is to grasp the relationship of coexistence, and at times, discord, between anticommunism and popular culture through a historical and chronological survey. To do this, this paper will first seek to understand anticommunism as an ideology with consistent logic, but a as a diverse and multilayered, mutable and contradictory affect. This gives the advantage of viewing anti-communism not from the aspect of its production, but of its acceptance. This can provide a clue as to why anticommunism, which wields unsurpassed power at present in the world's only divided nation, Korea, compulsively defends itself while constantly in a state of insecurity and ambiguity while facing challenges and resistance, and endless cracks form in its logic. This paper consider the influence exerted by anticommunism on "anticommunist films" and the reconstruction of the conditions of "anticommunism" by "anti-communist films" as two dimensions of the changing face of anticommunism circulating in popular sentiment through an analysis of the honeymoon/conflict relationship between anticommunism and popular culture.
\end{abstract}

Introduction: anticommunism as affectual response in popular culture

The goal of this paper is to grasp the relationship of coexistence and conflict between anticommunism and popular culture through a historical and chronological survey (Chin-ki et al. 2008, 2009; Sanghur Society 2005; Hŭi-yŏn 2003; Fuji, Takeshi 2011; Fuji Takeshi 2011; Takeshi 2008; Chŏng-hun \& Hŭi-yŏn 2003; Chun-hyŏn, Kim 2007; Lee, Hana 2012). ${ }^{1}$ Therefore this paper argues that anticommunism is not an ideology with a consistent logic, but rather a diverse and multilayered variable affect (Lee 2013a). ${ }^{2}$ This gives the advantage of viewing anti-communism not from the viewpoint of its production but of its acceptance, and can provide a clue as to why anticommunism, which wields unprecedented power over Korea today, the world's only divided nation, compulsively seeks to defend itself from challenges and resistance in a constant state of insecurity and ambiguity, and into the endless cracks in its logic.

The deep rooted origins of Korean anticommunism can be traced back to a few stages after the colonial period. The beginnings of "anticommunism" as a counterrevolutionary label to suppress the communist movement, a core force in the liberation movement from Japanese colonial rule, surfaced in the confrontation between the left

(C) 2016 The Author(s). Open Access This article is distributed under the terms of the Creative Commons Attribution 4.0 International License (http://creativecommons.org/licenses/by/4.0/), which permits unrestricted use, distribution, and reproduction in any medium, provided you give appropriate credit to the original author(s) and the source, provide a link to the Creative Commons license, and indicate if changes were made. 
and right wing camps over building the new nation post-liberation and political differences in the 1945 Moscow Conference ignited nationalist sentiment. Leftist communists in the military were blamed for the violence and bloodshed in the Jeju Uprising and Yeosu-Suncheon Rebellion that occurred around the founding of the South Korean government, which triggered feelings of horror and insecurity towards communism on a wide scale (Dŭk-chung 2009) ${ }^{3}$ and induced South Korean society to turn sharply to the right. The outbreak of the Korean War was taken as evidence of North Korean communism's anti-nationalism, and afterwards the image of war and animosity towards communism was mass-reproduced through national education and propaganda in popular culture. Anticommunism was not merely animosity towards communism or North Korea but animosity towards dissenting forces and class conflict within South Korean society, and served as the basis of support for the far right anticommunist regime. Thus, the genesis, maintenance, and consolidation of this animosity desperately sought the veneer of popular culture.

Film was anticipated as the strongest propaganda tool in popular culture for effectively expanding anticommunism and interiorizing it among the citizenry, ${ }^{4}$ and was already well known as the "second bullet" in the US and UK propaganda films of World Wars I and II. Bureaucrats seeking to use film as another type of psychological warfare argued for modeling the strategies of Soviet and North Korean propaganda films. Needless to say, anticommunism exerted a powerful influence on film during its peak in popular culture in the 1950s and 60s, television's peak beginning in the 1970s and 80s, and continued doing so during film's second peak post-1990. So-called "anticommunist films" flying the banner of anticommunism were produced with extensive government support since the anticommunist regime launched by the Park Chung-hee regime in the 1960s until the June 1987 democratic struggle. As a result, South Korea became unique among anticommunist countries for "anticommunist films" that constituted an independent genre. ${ }^{5}$ The form and content of "anticommunist films" changed according to the establishment and collapse of Cold War regimes, stances taken towards North Korea, and influence of Hollywood genre films. In particular, they faced challenges in reflecting, reproducing, and playing variations of generational attitudes towards anticommunism (Byun, Jai-Ran 2001). ${ }^{6}$ Thus the changing state of anticommunist films is an appropriate text for examining how the populace understood and accepted anticommunism according to the times. This paper will examine changes in the circulation/consumption of anticommunism as a popular affect through analyzing the relationship of coexistence/conflict between anticommunism and popular culture in light of the influence exerted by anticommunism on "anticommunist films" and how "anti-communist films" reconstructed the criteria for "anticommunism."

\section{The criteria of anticommunism and its coexistence and conflict with popular culture}

1950-60s: anticommunism and humanism

The label of "anticommunist films" refers to films produced with the goal of arousing anticommunist consciousness or films with anticommunist themes, but the concept did not have clear stipulations upon inception. The first so-called "anticommunist films," Breaking the Wall (Sŏngbyŏk ŭl ttulk'o, dir: Han Hyŏng-mo, 1949) A Fellow Soldier 
(Chŏnu, dir: Hong Kae-myŏng, 1949) and the first female spy narrative The Hand of Destiny (Unmyŏng ŭi son, dir: Han Hyŏng-mo, 1954) were not labelled as "anticommunist films" at release. Although the Korean War was the critical factor in antagonizing North Korea for the South Korean populace, anticommunism was not the ruling ideology or mentality of South Korean society in its immediate aftermath. The "anticommunist film" label also began to be widely used beginning in the mid-1950s over the course of a series of debates over what was anti-communist (Chung, Young Kwon 2010). ${ }^{7}$ This was of extremely important significance in creating a popular consensus of anticommunism. As a type of affect based on animosity towards the other, the ideological offensive of anticommunism in a far right anticommunist nation needed an educational process constantly differentiating and redefining what was and what was not "anticommunist" in order to gain popular acceptance. That the societal definition of what was and what was not "anticommunist" was still not clearly established even in the mid-1950s shows that the content of anticommunism was highly ambiguous.

The two pillars forming the core of "anticommunist films" were war films and spy films. ${ }^{8}$ The first Korean war film, the documentary An Assault of Justice (Chŏngŭi ŭi chin'gyŏk, dir: Han Hyŏng-mo, 1951) induced both the pleasure of spectacle and horror of war and was repeatedly used as the typical image of the Korean War even as recently as a few years ago. The swarming tanks, bombardments, and the blazing island of artillery fire across the horizon were treated as the most striking proof of how the 'Northern monster that illegally invaded the South unawares on a quiet night' was violent, destructive, antinationalist, and anticommunist in nature. Later war films played the role of constantly reminding the audience of the "brutalities" committed by the North Korean communists and greatly contributed to creating the horror of when North Korea might again wage war. Meanwhile, spy films depicting the proxy war between spies in South Korean society plotting its division and destruction and state power checking their activities functioned as bastions of preserving the status quo, prodding the audience to be always alert to the reality of national division. The image of spies infiltrating the dark margins of society, stirring all manner of societal conflicts and listening to the short-wave radio under cover of night, served to arouse a wariness of strangers in the midst of rapid urbanization and a fear of anonymity that instigated even more regional conflict. Counterespionage in spy films not only meant targeting the "indirect aggression" of spies dispatched to the South, but the assemblymen, students, citizens, and laborers "deceived and turned traitor" by the spies, with the intent of nipping the buds of class conflict, the democratization movement, and anti-regime struggles within South Korean society.

The biggest audience of "anti-communist films" were children and youth. The threat of war and indirect aggression became the basis of horror and fear of communism in which they were emotionally indoctrinated through a combination of anticommunist and ethics education. ${ }^{9}$ Anticommunist slogans, posters, essay and speech contests, and a significant amount of school routine were dedicated to expanding and strengthening anticommunism, and communists were described and constantly exposed as "horned goblins" and "wolves wearing rabbit masks." 10 Group screenings held by schools were the main form of consuming "anticommunist films," which played a large role in preserving unpopular "anticommunist films" for a significantly long time. 
However, the properties of the film medium and nature of the spy film genre at times completely backfired against the substitution of anticommunism in film. There were many cases of anticommunist films having the "unintended side effect" of arousing the united affect of national sentiment rather than the exclusionary affect of "anticommunism" (Lee 2013b; Lee, Hana 2011). ${ }^{11}$ Anticommunist films which were supposed to plant feelings of animosity towards North Korean communists also imprinted the affect of North Koreans as humans and North and South Korea as one nation. What then were the 1950-60 criteria for "anticommunism" that made it fall into its own contradictions in anticommunist films?

The surrounding debate over Piagol (Piagol, dir: Yi Kang-chŏn, 1955) and The Seven Female POWs (Ch'ilin ŭi yŏp'oro, dir: Yi Man-hŭi, 1965), two prominent war films typical of the period, provide an opportunity to reevaluate the criteria for "anticommunism" at the time (So-yŏn et al. 2003; Han-Sang, Kim 2011; So-yŏn 2003). ${ }^{12}$ The screening of both films was prohibited for violating the National Security Act, and in the latter's case, the director was charged with an arrest warrant. Piagol, which based its scenario on a press release from the North Chŏlla Province Police Department on the capture of the Ppalch'isan communist guerillas, had heavy backing and support from the military and police during production, but experienced difficulties in its premiere over growing differences in opinion within the government upon completion over its censorship. ${ }^{13}$ The Ministry of Education approved its premiere under the condition of editing or deleting several scenes, but the Armed Forces Information and Education Division in the Ministry of National Defense opposed the motion. In addition, although the Department of the Army's Office of Information and Education Division approved of the film, the Ministry of Home Affairs commented, 'It is difficult to see [Piagol] as an anti-communist film.' Meanwhile, critics spoke out in favor of Piagol as a great anticommunist film, ${ }^{14}$ but the rationales behind judging Piagol as an anticommunist film or not as such were in fact identical.

This was due to the theme of humanism pervading the film. The logic of espousing humanism, ${ }^{15}$ a feature of anticommunist films at the time, manifested in a dual form in anticommunist films. There was a great divide over whether to highlight humanist themes by showing the inhumane and immoral acts of the communists in order to criticize communism, or depict humanistic communists in order to juxtapose the superiority of humanism over communism. If it was a case of the former, Piagol should have been praised as a great anti-communist film, but if it was a case of the latter, it would be regarded as exerting a "bad influence" on society and extremely dangerous. This was because teaching the logic behind communism in order to criticize it had the reverse effect of possibly teaching audiences communist ideology. The fact that the protagonist, the object of the audience's empathy, was a communist violated the absolute antagonism that formed the basis of anticommunism.

The sympathy shown to the communist in this film is certainly not seen in other war films such as The Battle Line of Freedom (Chayu chŏnsŏn, dir: Kim Hong, 1955), Beat Back (Kyŏkt'oe, dir: Yi Kang-ch'ŏn, 1956), and A Cross in Gunfire (P'ohwasog ŭi shipchaga, dir: Yi Yong-min, 1956). These films understood the Korean War not as a conflict between the Republic of Korea Army and the North Korean People's Army, but between that of the UN forces and Chinese People's Liberation Army. This reflected 1950s anticommunism which deliberately situated Korea as the frontline of the Free 
World against the Communist Bloc. What made these three films undoubtedly "anticommunist" resulted from the fact that they precisely reflected what was implicated in the anticommunism of the time. Piagol stirred controversy over the extension of its humanism to include communists when an "anticommunist film" would have positioned them as inhumane and immoral, and highlighted the South Korean regime as its bearer of humanism. In the end, the Piagol superimposed the taegukki over the female protagonist in the final scene to clearly show her defecting to the South, quieting the dispute and barely securing its release.

The Seven Female POWs was also problematic for its humanism. In this film, the North Korean People's Army confront the Chinese People's Liberation Army in order to rescue South Korean female POWs. The communists are viewed from a humanist perspective and as part of the Korean nation. Although the "anticommunism" espoused by the government saw the Korean communists as traitors to the Korean nation, this film strongly highlighted the sentiment that the South and North were one nation. The communists are also presumed to be the protagonists and the audience is led along that line of thought by drawing sympathy for the inevitable fate of one of the communists. The title of Female POWs, which made it seem as if it was attached from the viewpoint of the North Korean army, also made the film's ideology highly suspect. The depiction of North Korea as an independent state also ran completely counter to the anticommunism of the time which saw North Korea as a puppet regime colluding with the Soviet Union. The instant that an "anticommunist film" such as Female POWs which was supposed to emphasize the fact that North Korea was a place which annihilated humanism and freedom advocated for the humanism of a North Korean communist, provided itself the basis for infringing on the National Security Act. In the end, the title of The Seven Female POWs was changed to The Returned Female Soldiers and released after the editing and deleting of problematic scenes.

However, problematic films such as The Seven Female POWs came to be called "anticommunist humanist films" after the mid-1960s. The filmmakers and critics who supported these films argued that their humanism was based on a high level of anticommunist consciousness. ${ }^{16}$ The government's logic behind anticommunism which held humanism should not be applied to North Korean communists in order to be thoroughly anticommunist could not help but back down from the opinion that humanism was an essential element of "anticommunism" and films with humanist themes were true "anticommunist films." If this was ignored, the basis of existence for many anticommunist films, as well as art films, would have been threatened in popular culture. This signified that the myth that anticommunism was a type of humanism had taken root throughout society, and thus the conflict between anticommunism and popular culture concluded with the ruling class tolerating the combination of anticommunism and humanism together. Anticommunism and the problem of humanism showed the changing face of anticommunism in popular culture and strongly influenced late 1960s anticommunist films.

\section{0-80s: anticommunism and entertainment}

With anticommunism and humanism no longer stirring conflict, a change occurred in "anticommunist" films. This change was the separation of North Korea's minority ruling class from its masses and an outpouring of sympathy and tolerance towards the 
latter, linking animosity to North Korea towards the antinationalist ruling class and embracing the North Korean masses as part of the same nation. This inevitably induced the weakening of anticommunism, or its inconsistency, due to famous anticommunist films such as Hero Without Rank (Kunbŏn ŏmnŭn yongsa, dir: Yi Man-hŭi, 1966) and others that sometimes strongly emphasized nationalism, creating cracks in anticommunism. That is, if communists were repentant and reflected, they would be accepted as part of the Korean nation. No ideology could surpass the family love equivalent to national love, as blood was thicker than water.

However, with the election of Park Chung-hee in the sixth presidential election in May 1967, South Korean society entered a preparatory phase for the Yusin dictatorial regime and the perspective on North Korea changed with growing conservatism. That is, anti-North Koreanism, which made all of North Korea, including its masses, targets of criticism, gradually grew stronger. ${ }^{17}$ This became even more so after 1968 with the Blue House raid by armed communist guerillas, the USS Pueblo Incident, and attacks and raids large and small in the demilitarized zone. With vigilance against North Korea on the rise, the importance of counterespionage was emphasized. Although it was already emphasized after the May $16^{\text {th }}$ coup de tat along with the growth of anticommunism, it was no longer possible to embrace agents, pawns of North Korean authority, as part of the nation during the late 1960s.

The late 1960s saw changes in "anticommunist films" in two ways. The first was that films directly portraying North Korean society began to appear. Films such as Accusation (Kobal, dir: Kim Su-yong, 1967), which depicted events within North Korean society, and war films such as Legend of Ssarigol (Ssarigol ŭi Shinhwa, dir: Yi Man-hŭi, 1967) and Dolmuji (Tolmuji, dir: Chŏng Ch'ang-hwa, 1967) were made with North Korean regions as combat settings. The film adaptation of Hwang Sun-wǒn's 1953 novel, Descendants of Cain, which focused on wartime North Korean society after liberation, was also made in this period. These portrayals of North Korean society had the effect of emphasizing that not only North Korea's ruling upper classes, but also its masses, had become different from South Korean society thanks to having been brought up under communism. The attention to the wartime period after liberation in particular meant that the South Korean government was endowed with the legitimacy of establishing the nation. Another change was the prevalence of spy films which began to be actively produced after the Park regime laid out and flooded the public from 1962 onward with the concrete anti-communist principles "victory over communism" and "counterespionage." After the release of the Hollywood smash hit 007: Dr. No (dir: Terence Young, 1962) in 1965, the spy film trend started to boom and international spy films set in Hong Kong or Japan were briskly produced after 1966.

These changes in the late 1960s can tell us why spy films in the 1970s frequently borrowed topics such as the wartime period after liberation and espionage activities in the South and North, which was a natural result of the combination of the above two trends. For example, the Special Investigations Bureau (T’ŭkpyŏl susa ponbu) series of six films from 1973 to 1976 highlighted the tragic lives of female spies forced to be government pawns and condemned the North Korean government as the root cause of this tragedy while emphasizing the legitimacy of the South Korean government. Until the 1960s, there were hardly any anticommunist films depicting the power of North Korea's upper echelons, but it is not difficult to 
assume the existence of a supreme headquarters issuing orders in the 1970s spy films. The meticulous and vicious methods of these authorities, not unlike that of criminal organizations, are not displayed on screen but their existence is meant to be criticism of the hinted at authorities behind the scenes.

The frequent appearance of such direct criticism of North Korean authorities is believed to have been influenced by the change in South-North relations in the 1970s. After the July $4^{\text {th }}$ Joint Declaration by South and North Korea, the Park regime emphasized the thorough inculcation of anticommunist education while exercising caution against the rise of groundless unification discourses. ${ }^{18}$ If anticommunist education prior to this period was emphasized at the level of elementary schools, it now had to criticize communism with a more theoretical approach. The core of their criticism was that the communists were responsible for the division of the South and North as a result of renouncing nationalism, thereby breaking up the left-right coalition in the colonial period. ${ }^{19}$ Therefore, at a tactical level, communism took on the appearance of collaborating with nationalism but their intent was to betray the nationalists and overthrow them in the end. ${ }^{20}$ Thus discussions of unification were only possible when armed with an anticommunist consciousness which should be practiced as a requisite condition for South-North dialogue. ${ }^{21}$ The basic premise of this logic meant that the July $4^{\text {th }}$ Joint Declaration was not an unconditional dialogue and unification but rather a "standoff without dialogue" that merely transitioned to a "standoff with dialogue" (The Institute of Counterespionage 1972). ${ }^{22}$ The visible effects of this manifested as espionage incidents, and thus the issue of counterespionage awakened the people to the fact that they were the subjects of this standoff.

The changing media environment was the key factor in 1970s "anticommunist films" emphasizing spy films over war films. The groundbreaking dissemination of television sets moved the center of gravity in popular culture from film to television, thereby developing the expression of more popular, entertaining, and titillating topics in order to attract the attention of viewers. Moreover, although the government extensively promoted anticommunist films, including the establishment of an "Excellent Anticommunist Film" in the 1966 Grand Bell Awards, they were gradually losing their popularity. Though the debate over how much entertainment could be allowed in anticommunist films existed since the 1950s, ${ }^{23}$ entertainment naturally became a feature during the growth of anticommunist films as a genre and the mass production of entertaining anticommunist films in the 1960s. After the 1970s, the gradually waning popular interest in "anticommunist films" had to become even more entertaining and popular in order to attract public attention. Now popularity = entertainment came to be regarded as a requisite condition of anticommunist films and the more of it there was, the better the anticommunist film. ${ }^{24}$ This signified that "anticommunist films" were doing away with enlightenment and propaganda, ${ }^{25}$ and films weak in these elements were already unable to perform their role and function as "anticommunist films." If humanism was the hot potato that was the sticking point of the 1950-60s, then entertainment became the double-edged sword of the 1970-80s aimed at "anticommunist films."

1970-80s television and film distinguished itself with spy investigation dramas which emphasized entertainment. Chief Inspector (Susa banjang), which aired on MBC from 1971 to 1984, the most representative crime investigation drama and Investigation Headquarters (Susa bonbu), the representative spy investigation drama which aired 
from 1973 to 1983 on MBC, were massively popular. ${ }^{26}$ In addition, the Special Investigations Bureau film series dealt with real female spies in five of its six films. The frequently used topic of "Women doomed to live lives of suffering in the cruel prison of society and their time period" induced affects of sorrow and grief. The affect of "merriness" encouraged by dictatorial regimes since Japanese rule (Rae-sŏp 2011; Chung-Kang, Kim 2011) ${ }^{27}$ did not readily appear in popular culture, and comedy, the only merry form of entertainment, was left unrecognized over its lowbrow controversies. Female spies did not exist as selves who acted accordingly to their beliefs and values, but were merely depicted as taking orders from authorities behind the scenes or forced to give up their espionage after falling into the dilemma of love. There were no longer any disputes over whether communists should be treated as humans or seen as the same nation, but instead teary and fatalist sentimentalism became a criterion for the popularity of "anticommunist films."

Despite the fact that Korean films in the 1970-80s were in decline, "anticommunist films" saw steady production in the midst of these conditions. ${ }^{28}$ The narrative of spies working in secret abroad to threaten peace and security on the Korean peninsula featured prominently when the security logic of anticommunism took root in the 1980s. South Korean agents cracking down on spies in the international intelligence wars as protagonists were made into a type of film genre. Audiences were no longer interested in "Why he/she was forced to be a spy," and as avid fans of Hong Kong action films, sometimes consumed spy films merely as Korean action films. This made the existence of anticommunist films themselves difficult, and the more anticommunism was emphasized, the further they distanced themselves from audiences. Films that toned down anticommunism and borrowed it only as subject matter were so non-ideological to the point that they were embarrassed to be even called "anticommunist films." Such dismissal of "anticommunist films" from the public was a sign that though they might have been employed as tools of suppression, the public was turning away from them out of their own voluntary sentiment.

\section{Challenges and variations in anticommunism}

1990-2000: democratization and an introspective gaze

Post-1987, South Korean society's aspirations for democratization and the global atmosphere of the Cold War presented new challenges for anticommunist films. A formidable challenge to anticommunism arose from a sense of solidarity based on ethnic homogeneity with North Korea. The visit to North Korea in 1989 by Reverend Mun Ikhwan, Im Su-kyŏng, and other figures in the democracy movement implied that the fervor for South Korea's democratization would extend to fervor for unification. The slogans of 'minjung' and 'minjok' that were essential to the diverse cultural performances such as 'song movement' and 'art movement' in the 1980s protest culture of the universities indicated that democratization and unification were always inextricably linked. In this atmosphere, the first appearance of films questioning anticommunism, exemplified in 1990s war films such as North Korean Partisan in South Korea (Nambugun, dir: Chŏng Chi-yŏng, 1990), The Silver Stallion Will Never Come (Ǔnma nŭn oji annŭnda, dir: Chang Kil-su, 1991) and Spring in my Hometown (Arŭmdaun shijŏl, dir: Yi Kwangmo, 1998), were signs of cracks within anticommunism. The films, which dealt with the 
fate of individuals and conflict within the community in a war setting, did not center the conflict on the South and North. On the contrary, the United States army (foreign powers) were regarded as providing the source of the conflict and arriving to aid in destroying the community with an ideology incomprehensible to Koreans' lives, as well as a war wherein the reasons for fighting could not be ascertained.

North Korean Partisan in South Korea's protagonist is a journalist who is not devoted communist but becomes a party member when joining the rank and file of the Ppalch'isan guerillas. However, he is captured in the end by punitive forces after wandering the snow-capped mountains while straggling behind. Although Piagol was doubted to be an "anticommunist film" due to the ROK army not appearing, the ROK army here destroys Ppalch'isan guerillas as a repressive punitive unit. Despite that, the film's Cold War atmosphere is still enough to take shots against anticommunism. The protagonist is arrested by the military and police according to the source novel written by a real journalist following the Ppalch'isan guerillas, (Tae 1988) ${ }^{29}$ but in the film the scene is omitted for an ending with the protagonist's face of despair at the complete annihilation of the Ppalchi'san guerillas. In other words, the film's protagonist does not defect to South Korea. In contrast to Piagol, which unnaturally superimposed a waving taegukki over the protagonist's face in order to prove it was an "anticommunist film," this ending aims not to be "anticommunist film" but attempts to eloquently attack anticommunism. The film's thematic awareness is to show the meaninglessness of ideology by shedding light on an individual swept up in the whirlpool of history.

The protagonists in The Silver Stallion Will Never Come and Spring in my Hometown are not soldiers but normal people living in traditional communities. However, after the rape of the simple women by the US army on their return and the inflow of American culture, they set foot on the path of misfortune and the traditional community is destroyed. The essence of the Korean War in these films is not the South-North conflict, but of that between the Korean people and foreign powers. The America portrayed as a friendly nation as part of the blood alliance in 1950s films appears as the primary cause of conflict in 1990s films. The sense of identity of a member of a Free World, the most basic principle of anticommunism, appears nowhere in these films. Instead, it is the avaricious soldiers of empire who insult the natives as occupying forces and a nation lacking self-esteem that cannot remove them. This not only clearly reflects the collapse of the political binary logic of the period but is an extension of the voicing of anti-American slogans by protesting intellectuals, citizens, and students. The most important mode of past "anticommunist films," the war film, was now the genre most harshly criticizing anticommunism.

In addition, while war films did not directly portray battles, they still had the disadvantage of high production costs due to the survival of "anticommunist films" through government support under the 'Excellent Film' system since the 1950s (Lee Hana 2012). ${ }^{30}$ If one recalls that the many war films and "national films" in the 1960-70s were made under the systemic support of the Ministry of National Defense, ${ }^{31}$ it was no longer possible to make war films which demanded a degree of spectacle without government support even as "anticommunist films." War films centered on combat made their reappearance with the release of 2004's Taegukgi (T'aegŭkki hwinallimyŏ, dir: Kang Che-kyu). The revival of such war films contributed greatly to the explosive growth of the Korean film market from 1990 to the early 2000s. ${ }^{32}$ 
However, despite Taegukgi being born purely out of interest in the war film genre, it ironically could not veer away from the inevitable ideological debates undergone by past anticommunist films. Struggling to procure a budget of 14,700,000,000 won, the most expensive budget at the time, the producers requested aid from the Ministry of National Defense, but were refused on the issue that the film could become "extremely dangerous." The attitude of the protagonist lacking the consciousness of a soldier towards to the war and his only becoming a member of the North Korean People's Army in order to save their younger sibling was problematic as it was likely to make youth evade the military and despise war. Moreover, the treatment of sensitive issues such as the Bodo League Massacre, punishment of collaborators and civilian massacres presented the problem of South Korea's immoral handling of the war. On the other hand, the conservative connotation of the title and the protagonist aiming their gun at the North Korean army at the end made the film seem as if it was an extension of "anticommunist films." However, the film differed starkly from past "anticommunist films" by viewing the Korean War as clearly a South-North conflict and attempting reconciliation through the metaphor of brotherly strife, as well as attempting to criticize South Korea's failure in protecting the lives of its people. Moreover, the difficulty of anticommunism's exclusionary affect to interfere with strong nationalism analogized in the family is in fact seen in 1960s war films ${ }^{33}$ and Taegukgi can be viewed as a case where anticommunism is betrayed by anticommunist film subject matter.

Although there are slight differences in opinion over whether Taegukgi is a new variant of "anticommunist film" bearing the trappings of the genre or a post-Cold War antiwar film, there is no debate that the films following it such as Welcome to Dongmakgol (Welk'ŏm t'u tongmakkol, dir: Pak Kwang-hyŏn, 2005) and The Front Line (Kojijŏn, dir: Chang-hun, 2011) have totally different viewpoints of the Korean War and North Korea from past anticommunist films. Dongmakgol shows the original pure form of Korean people dressed in white simply living their lives unaware of war or ideology. It is the UN forces on the contrary who destroy the community, which is saved by the cooperation of South and North Korean soldiers. Similar to the portrayal of a Korean peninsula without strife before the war in Taegukgi, Dongmakgol also portrays the place free of conflict. In the end, the themes of the South Korean people as victims and the "simple" village being destroyed by assaulters who are not communists but Americans leading the foreign powers are seen in The Silver Stallion Will Never Come and Spring in my Hometown and continued in Dongmakgol and A Little Pond (Chagŭn yŏnmot, dir: Yi Sang-u, 2009). A Little Pond especially portrays a strong antiwar and anti-American stance from the standpoint of the victims. The No Gun Ri Massacre portrayed in a documentary style in this film may inadvertently ignore the Korean War's essence as a civil war. If most war films such as Taegukgi and The Front Line adopt extreme realism, Dongmakgol and $A$ Little Pond express a nationalist ideal embellished with fantasy. This nationalist sentiment which presumes that South and North are part of the same community is no different from overt criticism of anticommunism which desires South Korea's monopoly over legitimacy and exclusion of North Korea from the nation.

Furthermore, Dongmakgol and A Little Pond criticize the South Korean state as Taegukgi did. An isolated South Korean soldier in Dongmakgol, overcome with guilt after detonating a bridge full of refugees on the Han River under his superior's orders, 
deserts and attempts suicide. This shows the immorality of the power elite's orders to remove their nation's people by killing them rather than protecting them, while implying their lack of legitimacy in ruling the nation. In A Little Pond, the South Korean state is hardly present in the film after it transfers wartime control to the US and is powerless to stop the killing of its own people. In The Front Line, this viewpoint becomes even clearer. In this film, South Korea is shown to be so weak and incompetent that they are pushed around by the US at the ceasefire negotiation table. Collaborators are quickly dealt with but the punishment of pro-Japanese is unfinished to an extent that it is equivocal. Protecting the lives of civilians is not even considered, let alone the lives of soldiers at the front. The writer of Joint Security Area (Kongdong kyŏngbi kuyŏk JSA, dir: Pak Chan-wook, 2001), which dealt with the friendship of South and North Korean soldiers forced to confront each other, also wrote The Front Line where South and North Korean soldiers meaninglessly shoot at each other and then interact and sympathize. The nationalist narrative of South and North Korean soldiers sharing the same sentiments as part of one nation despite warring with each other but not based on fantasy did not stop with Joint Security Area, but continues to be portrayed in films following Taegukgi.

War films of the 1990-2000s were produced not only at a higher level of quality than that of the low-grade genre of past anticommunist films, but criticized and challenged them. These films carried two viewpoints. One was that instead of viewing North Korea from the "anticommunist" viewpoint of exclusion, they saw it from a combined perspective of "nation" and the other was grounding the film as a reflection on the South Korean nation. Films began to boldly question the South Korean nation particularly after the change in government with the Kim Dae-jung administration. After democratization, the freedom of expression granted to filmmakers as well as post-Cold War and post-nationalist trends made it possible to do the unthinkable in questioning South Korea's legitimacy.

\section{Recent trends: anti-North Korea and the victor's gaze}

Does this mean that these changes have allowed for a post-Cold War way of thinking to completely take over the Korean peninsula and made it so popular culture can no longer tread the path of anticommunism? A war film released in 2010 proved this was not so. At the premiere of 71-Into the Fire (P'ohwa sogŭro, dir: Yi Chae-han, 2010), critics pointed out the film was conservative to the point that it was "anachronistic," but its blockbuster numbers of over 3,000,000 viewers demonstrated that the Cold War still persisted either in reality or in the mentality of audiences today. The conflict of this film was clearly between South and North and more precisely between South Korean student soldiers and a North Korean army general. This North Korean army general differs from the archetypical communist of past anticommunist films who were coarse and inhumane and existed to show the cruelty of communism; he flaunts a unique charisma and even has a human side, giving the student soldiers time to surrender for the reason that they were students and not soldiers. Heading to Pohang under orders from the Supreme Leader to occupy Busan by August 15, he underestimates the student soldiers in his arrogance and misjudgment, giving them time to join with the UN forces and losing the opportunity to win the battle.

However, recalling that Kim Il-sung's complete victory in the North Korean power struggle occurs after the war and the Supreme Leader system is established in the early 
1970s, (Chong, U-kon 1997) ${ }^{34}$ it is difficult to imagine a North Korean general during the Korean War suppressing the oppositional faction by the reasoning that the Communist party and Supreme Leader are not the same and direct orders from the Supreme Leader should be followed. This film's imagined general more closely reflects the abstract "enemy" in the minds of South Korean conservatives who returned to power in 2008 rather than a real general in the 1950s. This film differs from post-1990 war films by clearly establishing the fact that the Korean War was an invasion of the South by the North, not unlike Cold War anticommunist films, but is more anti-North Korean than anticommunist by presuming that the "enemy" is the Supreme Leader, and not the party, that embodies communist ideology. Anti-North Koreanism, which began to appear in the late 1960s, came to pervade all of popular culture after it no longer had any targets with the fall of real socialism, criticizing the altered form of socialism in North Korea which differed from socialist countries of the past.

This film, based on the true story of young students risking their lives on the battlefield for a young and still yet powerless nation, is no different than an epic poem dedicated to the 71 students who gave up their lives for the birth of the nation. The scenes of student soldiers resolutely writing a pledge in their blood and their mothers calmly sending them off to battle overlaps with propaganda war films in the last days of the Japanese empire (Lee, Hana 2013). ${ }^{35}$ Despite the government being merely two years old, the students are fully determined to save the "nation" from communism, and these images overlap with those of wartime right wing organizations' fanatic sweep of leftwingers and the baptism of far-right youths in anticommunist education post-1970s. The film clearly presumes the "Republic of Korea" as a counterpart to North Korea and features the same sentimental context and emphasis on patriotism and the legitimacy of the "Republic of Korea" advocated by right-wing scholars in the left-right wing debates over contemporary Korean history and textbooks in late 2010. Moreover, South Korean conservatives perceived the 2002 Korean maritime border incidents, 2008 Kŭmgang Mountain tourist shooting, 2010 ROKS Chŏnan sinking, and the third North Korean test trial of nuclear missiles as a sequence of events wherein North Korea threatened the existing peace in East Asia, and thus emphasized the founding and patriotism for the "Republic of Korea" as a counterpart to the North.

This new anti-North Koreanism appears in several forms in popular culture. In late 2011, comprehensive television programming channels broadcast the first airwaves of programming on North Korea in various forms. Channels such as TV Chosun (TV Chosŏn) which allocated much of its news programming on North Korea and the entertainment program Now On My Way to Meet You (Ije mannarŏ kamnida) on Channel A particularly expend their efforts into reproducing variants on anti-North Koreanism in the present day. On the internet, the community board Ilbe, mainly operated by farright netizens, publicly advocates a twisted form of patriotism and anti-North Koreanism. Spy films descending from past anticommunist films are also a form of media which circulate this new variant of anti-North Koreanism. However, it is interesting to note that the spy drama IRIS, a spinoff of Swiri (Shwiri, dir: Kang Che-kyu, 1991) and the South Korean boy- North Korean girl melodrama The King 2 Hearts (Tŏk'ing t'uhach'ŭ, dir: Yi Che-kyu, 2012) vaguely rather than directly criticized the South and North Korea governments with their narratives of South and North Korea working together against international organizations fomenting war. Rejecting criticism of the North 
Korean ruling authorities while portraying extremist radicals as a minority was a way of slightly steering away from anti-North Koreanism.

However, recently released spy films actively portray the ruling authorities in North Korea as "behind the scenes villains." Spies under their command, or agents, are busy eking out a living (The Spy, Kanch'ŏp, dir: U Min-ho, 2012), constantly doubted by their superiors (The Berlin File, Perŭllin, dir: Ryu Sŭng-wan, 2012), or betrayed and discarded in the end (Secretly, Greatly, Unmil hage widae hage, dir: Chang Ch'ul-su, 2013). These ex-spies and spies are not the incarnations of ideologies in the past but merely scapegoats in the internal succession struggles after Kim Jong-il's death (Alumni, Tongch'angsaeng, dir: Pak Hŭng-su, 2012). After president Bush labelled North Korea as part of the "axis of evil," images of the country in Hollywood movies included it being the head of a barbaric international terrorist organization, a corrupt hereditary regime, and an immoral government with contempt for its people's safety. South Korean netizens, who even about 10 years ago would have boycotted Hollywood blockbusters negatively portraying North Korea, ${ }^{36}$ no longer show any repulsion towards South Korean films depicting North Korea as "villains." An even stronger antiNorth Koreanism is reproduced in these films which are more entertaining = popular and more humanist than past "anticommunist" films before them.

The Spy is a story of spies who will do anything for their family and money and are regarded as not particularly threatening by the South Korean government. To them, grandiose ideology nor the cause of "unification of the fatherland" is that important; what matters are their livelihoods and the safety of their families. The superior officer who comes down to order an assassination is strongly reminiscent of "coldblooded and heartless" killers frequently seen in past anticommunist films, and the person behind the order is of course the supreme authority in North Korea. The immorality and greed of the top North Korean authority behind the scenes also pressures the protagonist in The Berlin File. Here North Korea does not embody communism but only acts on its immoral authority to exploit the people to fill its own belly. In Secretly, Greatly, spies who have assimilated into a South Korean shantytown resist sudden orders from the party to commit suicide, and the authority behind the order seeks to assassinate them in preparation for their resistance. In Alumni, the ruling authorities in North Korea are not unified, and their power struggles are repeated between the spies in South Korea.

The North Korean ruling authorities aiming the dagger of betrayal at their people and their internal feuds, spies who assimilated into capitalist society and became accustomed to the people there, spies used and discarded because of both family and love, spies sacrificed in the power struggles over the hereditary regime, and South Korean agents viewing this all with pity are all frameworks frequently seen in 1970s anticommunist films and Special Investigations Bureau. This is none other than the viewpoint of South Korea as the victor, with a regime superior to the North's and the game having already ended with their victory. As shown in the box office numbers of over 7 million viewers of The Berlin File and Secretly, Greatly and over 1 million viewers of Alumni, the gaze of the victor is now ubiquitous among the South Korean populace. This gaze is problematic in that it makes young viewers naturally assent to anti-North Koreanism while consuming this genre of film and allows for regulating their political tendencies and perspectives on the issue of South and North Korea. ${ }^{37}$ 


\section{Results and discussion}

Viewing the changes in anticommunist films over the decades shows how anticommunism and popular culture ran in parallel or contradicted one another. The following results in this study can be summarized thus:

1. Anticommunist films were not clearly defined since their inception, and this was also true of anticommunism.

2. The many controversies over the coexistence of anticommunism and humanism in 1950-60s anticommunist films brought the ruling class to tolerate the combination of the two in the end. The combination of anticommunism's ambiguities with humanism on the contrary instilled awareness of North Korea as still part of the same people and nation.

3. With the wholesale decline of the film industry, 1970-80s anticommunist films did not do well without a heavy dose of entertainment, and as a result, their ideology suffered for it. This was one sign that anticommunism as a whole was gradually growing further apart from the sensitivities of the populace.

4. The end of the Cold War worldwide and the democratization of South Korean society during the 1990-2000s brought new challenges to anticommunist films. War films, one of the two pillars of the genre, changed to having a self-examining perspective of the nation rather than focusing on anticommunism.

5. With the rise of conservative administrations again since 2008 and North Korea's nuclear tests and the third generation of the Kim dynasty, spy films, the other pillar of the genre, as well as war films, again showed a clear resurgence in anticommunist tendencies.

6. These variations over the decades in anticommunist films which portray the South-North conflict are in fact proxies for the South-South ideological conflicts.

In this way, "anticommunist films" do not necessarily spread anticommunism as claimed in the literature up till now. Although the films portray a South-North conflict, they in fact represent the South-South ideological conflicts in many instances. This can be seen in their function of seeking to unify the South Korean populace and politics and cutting off criticism of its institutions at the root rather than anticommunism having the goal of opposing North Korea or communism. Thus, "anticommunist films" that underwent changes and variants since democratization also at times had conflicting positions: supporting progressive politics by introspectively viewing the Cold War South Korean state itself, or supporting anti-North Koreanism and patriotism by criticizing South Korean administrations friendly to North Korea and progressives. The conservative regression under the Lee Myung-bak and Park Geun-hye administrations of so-called "87 institutions" won as a result of the June 1987 struggle has seen the production of many war films and spy films with antiNorth Korean characteristics. As seen above, Cold War "anticommunist films" carried tendencies that were not necessarily anticommunist in the process of acquiring mass popularity. Considering that they flaunted them openly after democratization, the prominence of South-South ideological conflicts in current politics as seen through war and spy films is due to the dualities and ambiguities existing in 'anticommunism.' 


\section{Conclusion: South-South ideological conflicts through proxy wars in popular culture}

In July 2015, Northern Limit Line (Yŏnpyŏng haejŏn, dir: Kim Hak-sun, 2015) was narrowly released with help from the government after over 7 years of halting development. Despite the lack of interest in film circles and critically harsh reviews, the film drew over 6 million viewers, making it a commercial success. The film, which dealt with a battle with North Korean forces on the Yellow Sea in June 2002 at the height of the World Cup fervor, could have been called a 'Veterans Safeguarding the Nation film' for glorifying the heroic sacrifice of the South Korean navy men. Despite merely emphasizing their individual sacrifices, its outspoken criticism of Kim Dae-jung's North Korea policy at the time shows that it had no interest in overcoming the anticommunism that Korean War films in the 2000s targeted. Moreover, analyses from each of the ruling and opposition party representatives that saw the film in light of the past administration's North Korea national security policies clearly exposed how anticommunism was a basis of right-wing claims in the South-South ideological conflict (i.e. left-right wing conflict in South Korea). The fact that the film's extreme right wing concept was the main culprit behind its cold reception in film circles and the causes of its production crises clearly illustrates this situation. As shown in the film, anti-North Koreanism in 'anticommunist films' was not expressed as opposing North Korea, but intensifying criticism of Kim Dae-jung's Sunshine policy which embraced North Korea, and its continuation by the Noh Mu-hyŏn administration and the consciousness of its supporters, as seditious and dangerous.

Although the world has now long left the Cold War period behind, the Cold War situation of tension in the Korean peninsula continues and anticommunism still wields a strong influence. Despite the meaninglessness of regime competition in the past, the fact that the National Security Act symbolizing anticommunism could not be abolished again reminds us that anticommunism was one of the supporting pillars of South Korea. While at a glance it seems that the red complex of the past has been overcome, anticommunism meanwhile is reproduced in the name of peace, security, and human rights, and continues to arouse anti-North Korean sentiment over the veneer of popular culture. "Anticommunist films" promoted as part of the nation's enlightenment in the Cold War period could not help but be fragmented in clashing with the popularity of genre films. The anticommunist sentiment that sought to exclude North Korea from the nation in past anticommunist films had difficulty in overcoming the combination of nationalist sentiment that induced both emotion and tears. It could be said post-1990 war films were fated to become commercial films filled with mostly nationalist sentiment that aimed for popular themes of humanism through a critical viewpoint of the South Korean government.

In addition, the more South Korea feels superior and confident to North Korea, the more spy films become more polished and vary into a form of "anti-North Korean film." Korean films which did not criticize the North Korean elite, acting as extensions of the people's government and participatory government's Sunshine Policy, regressed to the lineage of past traditional "anticommunist films," criticizing the North Korean elite and viewing the North Korean people used as their pawns with pity after the incoming of conservatives into power and the third generation of North Korean succession. On the contrary, if past "anticommunist films" treated the North Korean people 
as part of the same nation on the basis of homogeneity, the new "anticommunist films" today pity and tolerate them from the gaze of a victor from a fundamentally different existence. With the number of people who remember what it was like before division and those carrying the pain of separated families decreasing, the awareness of unification by the younger generation who enjoyed accelerated economic wealth after division weakening, and the decline of nationalism as an ideology and the poverty of logic behind unification in this age, the viewpoint of North Korea in popular culture is playing a role in strengthening the $38^{\text {th }}$ parallel in our minds.

However, anticommunism cannot but maintain an unstable existence in popular culture as the "nation" still resonates more strongly than "anticommunism" with the populace and reflection and criticism of the South Korea are in and of themselves the clearest criticisms of anticommunism. Anticommunism wearing the trappings of "anticommunist film" has lived with and evolved with popular culture but has also come into conflict with and created discord with it. As film is based on the sympathy of the populace, the popular circulation and consumption of anticommunist sentiment is not the same as that of the past. The left-right conflict in today's politics is embodied in anticommunist films versus non-(or anti-)anticommunist films, and thus while war and spy films on the surface deal with the North-south conflict, internally they are proxies of South-South ideological conflicts. Anticommunism is used to deflect blame for internal conflicts in South Korean society towards the other and as a suppression mechanism towards opponents and will continue to survive so long as the South-North conflict continues and South Korean society does not completely democratize. However, popular culture based on the affects of the populace will not allow anticommunism to continue in the same form of the past. This is why anticommunism and popular culture are fundamentally at odds with one another.

\section{Endnotes}

${ }^{1}$ For recent studies on anticommunism, see: Kim Chŏng-hun, Cho Hŭi-yŏn, Chibae tamnon ŭrosŏ ŭi pan'gongjuŭi wa kŭ pyŏnhwa - 'Pan'gong kyuyul sahoe' ŭi pyŏnhwarŭl chungshim ŭro [Anticommunism as a Dominant Discourse and its Changes - Focusing on an 'Anticommunist Regulated Society'], Cho Hŭi-yŏn ed., Han'gug ŭi chŏngch'i sahoejŏk chibae tamnon kwa minjujuŭi tonghak [Dominant Sociopolitical Discourses in South Korea and Dynamics of Democracy] (Seoul: Hamkke Ingnŭn Ch'aek, 2003); Fuji Takeshi, Che 1konghwaguk ŭi chibae ideollogi wa kŭ pyŏnyongdŭl [The Ruling Ideologies of the First Republic: Anti-Communism and its Variants], Yoksa Pip'yŏng 83 (The Institute of Korean Historical Studies, Summer 2008); Fuji Takeshi, 4-19/5-16 Shigi ŭi pan'gong ch'eje chaep'yŏn kwa kŭ nolli [The Reformation and Logic of the Anticommunist System of the April $19^{\text {th }}$ and May $16^{\text {th }}$ Period], Critical Studies in Modern Korean History 25 (The Institute of Korean Historical Studies, 2011); Fuji Takeshi, 1950-yŏndae pan'gong kyojae ŭi chŏngch'ihak [The Politics of 1950s Anticommunist Education Materials], Critical Studies in Modern Korean History 30, (The Institute of Korean Historical Studies, 2011); Lee Hana, 1950-60-yŏndae pan'gongjuŭi tamnon kwa kamsŏng chŏngch'i [1950-60s Anticommunist Discourse and Politics of Affect], Sociohistory 95 (Korean Social History Association, 2012), etc. There is abundant comparative research on anticommunism's influence on literature: Sanghur Society, Pan'gongjuŭi wa han'guk munhak [Anticommunism and Korean Literature], (Kip'ǔn Saem, 2005), Kim Jin Gi, 
et al., Pan'gongjuŭi wa Han'gung munhak ŭi kŭndaejŏk tonghak 1,2 [Anticommunism and the Modern Dynamics of Korean Literature Volumes 1 \& 2] (Seoul: Hanul, 2008, 2009), Kim Chun-hyŏn, Pan'gongjuŭi ŭi naemyŏnhwa wa 1960 -yŏndae p'ungja sosŏr ŭi han kyŏnghyang - I Ho-ch'ŏl Sŏ Ki-wŏn ŭi tanp'yŏn ŭl chungshim ŭro [The Internalization of Anticommunism and Trends in 1960s Satirical Novels - Focusing on the Short Stories of Yi Ho-ch'ŏl and Sŏ Ki-wŏn], Sanghur Hakbo 21 (Seoul: Sanghur Society, 2007), Kim Jin Gi, Pan'gongŭi naemyŏnhwa wa chŏngch'esŏng ŭi kuch'uk : Son Ch'angsŏp sosorrŭl chungshim ŭro [Internalization of Anticommunism and Construction of Identity - Focusing on the Novels of Son Ch'ang-sǒp], ibid. However, research focusing on the relationship between anticommunism and anticommunist films but not anticommunism itself is rather rare. Lee Hana, Kamsŏng kwa konggongsŏng: kamsŏng ŭi yŏksarŭl mutta; pan'gongjuŭi kamsŏng kihoek, "pan'gong yŏnghwa" ŭi tillema -1950 60 -yŏndae "pan'gong yŏnghwa" nonjaeng ŭl chungshim ŭro [Affect and Publicness; Questioning the Historicity of Affect: The dilemma of "anticommunist films" as a project of affect; With a focus on the "anticommunist film" arguments in the 1950's $\sim 1960$ 's], The Journal of Korean Studies 159 (Seoul: Yonsei Institute of Korean Studies, 2012).

${ }^{2}$ Ibid., pg. 204-205. In the above writing, the author understands anticommunism as an emotional complex combining diverse and contradictory logics and sentiments, classifying 1950s-60s anticommunism into ten general categories.

${ }^{3}$ Kim Dŭk-chung, Ppalgaengi ŭi t’ansaeng - Yŏsun sagŏn kwa pan'gong kukka ŭi hyŏngsŏng [The Birth of the 'Reds' - The Yǒsun Incident and Formation of the Anticommunist State] (Seoul: Sŏnin, 2009).

${ }^{4}$ Pak Se-hwa, Pan'gong t'aese kanghwarŭl wihan sogo [A Brief Study on Strengthening Anticommunist Readiness], Kyŏngch'al 2-4, 1963, pgs. 126-132.

${ }^{5}$ Although anticommunist films also existed in Hollywood, they cannot be seen as an independent genre developing over the course of decades. On 1920-30s Hollywood anticommunist films, see John J. Gladchuk, Hollywood and Anticommunism: HUAC and the Evolution of the Red Menace, 1935-1950, Routledge, 2013, pgs.115-130.

${ }^{6}$ There are possible differences of opinion over whether these can still be called "anticommunist films." Therefore, they are also labelled as "division films" rather than "anticommunist films." In order to explicate on "anticommunist films" here, we use the term "anticommunist film." On the definition of "division films," see Byun Jai-Ran, Namhan yŏnghwa e nat'anan Pukhan e taehan ihae [Understanding of North Korea appearing in South Korean Films -focusing on Swiri, Spy Lee Chul-Jin and Joint Security Area. JSA], Yŏnghwa yŏngu 16 (Han'guk Yŏnghwa Hakhoe, 2001).

${ }^{7}$ Chung Young Kwon, Han'guk pan'gong yŏnghwa tamnon ŭi hyŏngsŏng kwa chŏnjaeng yŏnghwa changnŭ ŭi kiwŏn 1949 1956 [A Study of the Formation of Discourse on Anti-communist Films and the Origin of War Film in South Korea between 1949 and 1956], Contemporary Film Research 10 (Hanyang University Contemporary Film Research Institute, 2010), pgs. 385-391.

${ }^{8}$ Although there are lowbrow genres of anticommunist films on the tragedy of national division such as social dramas, melodramas, and action dramas, these stories mostly take place during or after the war. The former usually are of films on the war and the latter with films on spies. Here war films refer to not only "combat films" which mostly have combat scenes, but a broader definition of films where war directly influences the narrative. In addition, although there are war spy films dealing with the 
activities of wartime spies, they are classified as war films or spy films depending on which aspect they emphasize. As most war spy films emphasized espionage activities rather than combat scenes, there are more cases of the latter.

${ }^{9}$ For anticommunist education as emotional education, see Lee Hana, ibid., pgs. 224-230.

${ }^{10}$ The cultural film Let's Not Deceive Again (Tashinŭn sokchi malja, dir: Pak Yŏng-il, 1964 ) is an animated film produced directly by the government where South Korean civilians are portrayed as rabbits and the North Korean people are depicted as wolf spies wearing rabbit masks.

${ }^{11}$ Lee Hana, ibid., pgs. $75-77$.

${ }^{12}$ For debates on 1950-60s anticommunist films, see Kim So-yŏn, Chŏnhu Han'guk ŭi yŏnghwa tamnon esŏ 'riŏllijŭm' ŭi ŭimi e kwan hayŏ: P'iagor ŭi met'a bip'yŏng ŭl t'onghan chŏpkŭn [On 'Realism' in Postwar Korean Film Discourse: A Metacritical Approach to Piagol], Kim So-yŏn, et al., Maehok kwa hondon ŭi shidae: 50 -yŏndae Han'guk yŏnghwa [The Age of Fascination and Chaos: Fifty Years of Korean Film] (Seoul: Sodo, 2003); Chung Young Kwon, Han'guk pan'gong yŏnghwa tamnon ŭi hyŏngsŏnggwa chŏnjaeng yŏnghwa changnŭ ŭi kiwŏn 1949 1956 [A Study of the Formation of Discourse on Anti-communist Films and the Origin of War Film in South Korea between 1949 and 1956], Contemporary Film Research 10 (Hanyang University Contemporary Film Research Institute, 2010); Kim Han Sang, Naengjŏn ch'eje wa naesyŏnŏl shinema ŭi honjongjŏk wŏnch'ŏn : Chugŏm ŭi sangja tŭng Kim Kiyŏng ŭi Migongpowǒn (USIS) munhwa yŏnghwarŭl chungshim ŭro [Cold War and the Hybrid Upspring of South Korean National Cinema -On Boxes of Death and Kim Ki-Young's USIS Public Information Films], Yŏnghwayŏngu 47 (Han'guk Yŏnghwa Hakhoe, 2011); Lee Hana, ibid.

${ }^{13}$ In 1955, the Ministry of National Defense, Ministry of Public Information, Ministry of Education, and Ministry of Home Affairs oversaw tasks regarding film before it became the Ministry of Education became the office of primary concern for films.

${ }^{14}$ Im Kŭng-chae, Sŏnjŏn kach'i wa yŏnghwa yesulsŏng - pan'gong yŏnghwa pip’an ŭi shibi t'ŭk'i P'iagorŭl chungshim hayŏ [Propaganda Value and Cinematic Aesthetics Anticommunist Film Criticism and Debates, Focusing on Piagol], Tonga Ilbo, 1955.8.12; Im Chŏng-sŏn, Han'guk yŏnghwa ŭi saeroun sŭt'ail - P'iagol ŭi sogam [The New Style of Korean Film - Thoughts on Piagol], Kyŏnghyang Sinmun, 1955.9.30.

${ }^{15}$ Lee Hana, ibid., pgs. 211-212.

${ }^{16}$ I Man-hŭi kamdog e kwandaehan ch'ŏbun ŭl [The Generous Treatment of Director Lee Man-hŭi], Tonga Ilbo, 1965.2.9; Yi Yŏng-il, 1965-yŏn naeoe yŏnghwa kyŏlsan Han'guk yŏnghwa ch'ongp'yŏng [An Evaluation of 1965 Domestic and Foreign Films A General Review of Korean Films], Yŏnghwa Yesul 1, 1996.

${ }^{17}$ For the refinement of anticommunism into anti-North Koreanism, see Lee Hana, ibid., pgs. 222-223.

${ }^{18}$ After the April $19^{\text {th }}$ Revolution, fervor for unification grew stronger throughout society and the historical experience of various unification theories being proposed can be seen as a cause of the Park regime focusing on suppressing other unification theories.

${ }^{19}$ Yun Chong-hyŏn, Kongsanjuŭi wa shin minjokchuŭinŭn ŏttŏn kwan'gye in'ga [How Are Communism and New Nationalism Related?], Sedae 13, 143, 1976, pgs. 150-157. 
${ }^{20}$ Kim Ch'ang-sun, Kongsanjuŭi wa minjokchuŭinŭn hapchaki kanŭng han'ga [Is Collaboration Between Communism and Nationalism Possible], Kukje Munje 66, 1976, pgs. 54-60.

${ }^{21}$ Oh Che-do, Nambuk taehwa wa p'yŏnghwa t'ongil [South-North Dialogue and Peaceful Unification], Byŏnhosa 5, 1974, pgs. 203-218.

${ }^{22}$ The Institute of Counterespionage ed., Chigong kyoyuk tokpon [Knowing Communism Education Reader] (Seoul: Hŭkbaek Munhwasa, 1972), pgs. 824-838.

${ }^{23}$ Lee Hana, ibid., pgs. 69-72.

${ }^{24}$ Kim T'ae-su, Kungmin ch'onghwarŭl wihan yŏnghwa yesul: Anbo yŏnghwa ŭi chejak panghyang kwa taejungsŏng [Cinematic Art for National Unification: The Popularity and Directions for Security Film Production], Korea Cinema May, 1972; Cho Yŏnhyŏn, Kungmin ch'onghwarŭl wihan yŏnghwa yesul: Anboyŏnghwa ŭi sojae wa kŭ kusŏng [Cinematic Art for National Unification: Topics and Composition of Security Films], Korea Cinema May, 1972.

${ }^{25}$ Kim So-tong, Pan'gong yŏnghwa ŭi sojae, p'yohyŏn, kŭrigo taejungsŏng [Topics, Expression, and Popularity of Security Films], Yŏnghwa 4-6 (Seoul: Yŏnghwa Chinhŭng Kongsa, 1976), pgs. 21-25.

${ }^{26}$ Although TV aired many dramas on war which were not popular as films, the most representative was the drama Comrades (Chŏnu) which aired from 1975-78 to 198384. This was made as a special feature on the $25^{\text {th }}$ anniversary of the Korean War by KBS and remade in 2010 by KBS on the $60^{\text {th }}$ anniversary of the Korean War.

${ }^{27}$ So Rae-sŏp, Puronhan Kyŏngsŏng ŭn myŏngnang hara: shingminji Chosŏn ŭl p'agodŭn kŭndaejŏk kamjŏng ŭi t’ansaeng [Make Rebellious Kyongsong Merry: The Birth of Modern Affect in Colonial Korea] (Seoul: Ungjin Chisik Hausu, 2011); Kim Chungkang, Hyŏndae Han'guk ŭi yŏnghwa chaegŏn nolli wa k'omidi yŏnghwa ŭi chŏngch'ijŏk hamŭi (1945-60) Myŏngnang hago yuk'wae han'palchŏn Taehanmin'guk' mandŭlgi [Making a Bright, Healthy Nation: Cinema Reconstruction Movement and the Politics of Comedy Film Production in the late 1950s' South Korea], Chin-Tan hakbo 112 (Chin-Tan Society, 2011).

${ }^{28}$ It is difficult to presume the exact number of "anticommunist films" as it can differ according to the definition of the category. According to statistics by a mid-1970s critic, there were a total of 242 films from 1946 to 1975, $8.99 \%$ of 2,736 theatrical features. The much lower number of theatrical features in the 1970 s to 80 s saw a similar proportion of anticommunist films. KIU, Sŏnggyŏk pŏl ro pon pan'gong yŏnghwa 30 -yŏn [Thirty Years of Anticommunist Films by Category], Yŏnghwa 4-6 (Seoul: Yŏnghwa Chinhŭng Kongsa, 1976), pg. 34.

${ }^{29}$ Yi T'ae, Nambugun [A North Korean Partisan in South Korea], (Seoul: Ture, 1988).

30"Excellent Films" were popular films selected by the government for coinciding with their aims of reconstructing the nation. See Lee Hana, 1950 -yŏndae minjok munhwa tamnon kwa 'usu yŏnghwa' [1950s National Cultural Discourses and "Excellent Films"], Yŏksa Pip'yŏng 92 (The Institute for Korean Historical Studies, 2011).

${ }^{31}$ Ministry of National Defense, Order 89. Kunsa kwan'gye yŏnghwa chejak chiwŏn kyujŏng [Regulations on Support for the Production of Military-Related Films], 1965.11.3.

${ }^{32} 1999$ 's Swiri (Shwiri, dir: Kang Che-kyu, 1999) mobilized over six million viewers, beating the 1998 release of the Hollywood blockbuster Titanic's (dir: James 
Cameron, 1997) record of 5.2 million viewers. A Korean film defeating an American film at the box office was also a nationalist aspiration here. Korean films, which were less than $30 \%$ of box office sales, continued to grow to $60 \%$ in 2006, dropping in 2007 and then recovering in 2009. As of August 2013 they make up $89 \%$ of box office sales.

${ }^{33}$ Lee Hana, Taehan min'guk, chaekŏn ŭi sidae (1948-1968) [The Republic of Korea: The Age of Reconstruction (1948-1968)] (Seoul: Purun Yuksa, 2013).

${ }^{34}$ Chong U-kon, Pukhan suryŏngje chŏngch'i ch'eje ŭi chedohwa wa t'ŭksŏng [The Systemization of North Korea's "Supreme Leader" Political Institution and its Characteristics], The Korean Journal of Unification Affairs 9-1 (The Institute for Peace Affairs, 1997).

${ }^{35}$ Lee Hana, The Unending War: Continuity and Rupture in Korean War films in Post-Cold War Era, SOAS Conference 2013, London University, 2013.5.31

${ }^{36}$ This refers to the release of 007: Die Another Day (dir: Lee Tamahori) in 2002. The actor Ch'a In-p'yo refused to be cast in the film since the film belittled North Korea.

${ }^{37}$ However, these films cannot be said to be deliberately inspiring anti-North Koreanism. While preparing to star in The Berlin File, the director Ryu Sŭng-wan also appeared in an interesting TV documentary called Time (T'aim Ryu Sŭngwan kamdok ŭi kanch'ŏp, MBC, 2011). The director and a journalist try to find the spy but fail in the end, and the film harshly satirizes South Korean's society's discourse on espionage. The film is sometimes more effective than the director and producer had intended.

\footnotetext{
Acknowledgement

The first draft of this paper was written for a project comparing anticommunism in Germany and South Korea. I am grateful to the supervisors of this project, namely Christoph Pohlman, the head of Seoul branch of the Evert Foundation in Germany and Professor Dongchun Kim of Sungkonghoe University in South Korea. I would like to take this opportunity to thank Andrew David Jackson, Associate Professor of the University of Copenhagen in Denmark, who offered me two opportunities to present my papers in Europe.
}

Competing interests

The author declares that she has no competing interests.

Received: 29 March 2016 Accepted: 2 August 2016

Published online: 04 October 2016

References

Byun, Jai-Ran. 2001. Namhan yŏnghwa e nat'anan Puk'han taehan ihae [Understanding on North Korea appearing in South Korean Films -focusing on Swiri, Spy Lee Chul-Jin and Joint Security Area. JSA], Yŏnghwayŏngu 16. Han'guk Yŏnghwa Hakhoe.

Chin-ki, Kim, et al. 2008, 2009. Pan'gongjuŭi wa Han'guk munhak ŭi kŭndaejŏk tonghak 1,2 [Anticommunism and the Modern Dynamics of Korean Literature Volumes 1 \& 2]. Seoul: Hanul.

Chong U-kon. 1997. Puk'an suryŏngje chŏngch'i ch'ejeŭi chedohwa wa t'ŭksŏng [The Systemization of North Korea's "Supreme Leader" Political Institution and its Characteristics], The Korean Journal of Unification Affairs 9-1. The Institute for Peace Affairs.

Chŏng-hun, Kim, and Cho Hŭi-yŏn. 2003. Chibae tamnon ŭrosŏ ŭi pan'gongjuŭi wa kŭ pyŏnhwa - 'Pan'gong kyuyulsahoe' ŭi pyŏnhwarŭl chungshim ŭro [Anticommunism as a Dominant Discourse and its Changes Focusing on an 'Anticommunist Regulated Society']. In Han'guk ŭi chŏngch'l sahoejŏk chibae tamnon kwa minjujuŭi tonghak [Dominant Sociopolitical Discourses in South Korea and Dynamics of Democracy], ed. Cho Hŭi-yŏn. Seoul: Hamkkeingnŭnch'aek.

Chung, Young Kwon. 2010. Han'guk pan'gong yŏnghwa tamnon ŭi hyŏngsŏng kwa chŏnjaeng yŏnghwa changnŭ ŭi kiwŏn 1949 1956 [A Study of the Formation of Discourse on Anti-communist Films and the Origin of War Film in South Korea between 1949 and 1956], Contemporary Film Research 10. Hanyang University Contemporary Film Research Institute.

Chung-Kang, Kim. 2011. Hyŏndae Han'gugŭi Yŏnghwa Chaegŏnnolliwa K'omidi Yŏnghwaŭi Chŏngchíijŏk Hamŭi (1945-60) Myŏngnanghago Yuk'waehan 'Palchŏn Taehanmin'guk' Mandŭlgi [Making a Bright, Healthy Nation: Cinema Reconstruction Movement and the Politics of Comedy Film Production in the late 1950s' South Korea], Chin-Tan Hakbo 112. Chin-Tan Society.

Chun-hyŏn, Kim. 2007. Pan'gongjuŭi ŭi naemyŏnhwa wa 1960-yŏndae p'ungja sosŏr ŭi han kyŏnghyang - I Ho-ch'ŏl Sŏ Kiwŏn ŭi tanp'yŏn ŭl chungshim ŭro [The Internalization of Anticommunism and Trends in 1960s Satirical Novels Focusing on the Short Stories of Yi Ho-ch'ŏl and Sŏ Ki-wŏn], Sanghur Hakbo 21. Seoul: Sanghur Society. 
Dŭk-chung, Kim. 2009. Ppalgaengi ŭi t'ansaeng - Yŏsun sagŏn kwa pan'gong kukka ŭi hyŏngsŏng [The Birth of the 'Reds' - The Yossun Incident and Formation of the Anticommunist State]. Seoul: Sŏnin.

Fuji Takeshi. 2011. 4-19/5-16 shigi ŭi pan'gong ch'eje chaep'yŏn kwa kŭ nolli The Reformation and Logic of the Anticommunist System of the April $19^{\text {th }}$ and May $16^{\text {th }}$ Period], Critical Studies in Modern Korean History 25. The Institute of Korean Historical Studies.

Fuji, Takeshi. 2011. 1950-yŏndae pan'gong kyojae ŭi chŏngchïhak [The Politics of 1950s Anticommunist Education Materials], Critical Studies in Modern Korean History 30. The Institute of Korean Historical Studies.

Han-Sang, Kim. 2011. Naengjön ch'eje wa naesyŏnŏl shinema ŭi honjongjök wŏnch'ön: Chugŏm ŭi sangja tŭng Kim Kiyŏng ŭi Migongbowŏn (USIS) Munhwa yŏnghwarŭl chungshim ŭro [Cold War and the Hybrid Upspring of South Korean National Cinema -On Boxes of Death and Kim Ki-Young's USIS Public Information Films], Yŏnghwa Yŏngu 47. Han'guk Yŏnghwa Hakhoe.

Hŭi-yŏn, Cho (ed.). 2003. Han'guk ŭi chŏngch'l sahoejŏk chibae tamnon kwa minjujuŭi tonghak [Dominant Sociopolitical Discourses in South Korea and Dynamics of Democracy]. Seoul: Hamkkeingnŭnch'aek.

Kyŏngch'al; Kukje Munje; Byŏnhosa; Sedae; Yŏnghwa; Yŏnghwa Yesul; Korea Cinema; Tonga Ilbo; Kyŏnghyang Sinmun. Lee, Hana. 2013a. Kukga wa Yŏnghwa [The Nation and Cinema]. Seoul: Hyean.

Lee, Hana. 2013b. Taehan min'guk, chaekŏn ǔi sidae (1948-1968) [The Republic of Korea: The Age of Reconstruction (19481968)]. Seoul: Purun Yuksa.

Lee Hana. 2012. 1950-60-yŏndae Pan'gongjuŭi tamnon kwa kamsŏng chŏngch'i [1950-60s Anticommunist Discourse and Politics of Affect], Sociohistory 95. Korean Social History Association.

Lee Hana. 2013. The Unending War: Continuity and Rupture in Korean War films in Post-Cold War Era, SOAS Conference 2013. London University. 5.31.

Lee, Hana. 2011. 1950-yŏndae minjok munhwa tamnon kwa 'usu yŏnghwa' [1950s National Cultural Discourses and "Excellent Films"], Yŏksa Pip'yŏng 92. The Institute for Korean Historical Studies.

Lee, Hana. 2012. Kamsŏnggwa konggongsŏng: Kamsŏng ŭi yŏksarŭl mutta; Pan'gongjuŭi kamsŏng kihoek, "pan'gong yŏnghwa" ǔi tillema -1950 60-yŏndae "pan'gong yŏnghwa" nonjaengŭl chungshim ŭro [Affect and Publicness; Questioning over the Historicity of Affect : The dilemma of "anticommunist films" as a project of affect; With a focus on the "anticommunist film" arguments in the 1950's 1960's], The Journal of Korean Studies 159. Seoul: Yonsei Institute of Korean Studies.

Rae-sŏp, So. 2011. Puronhan Kyŏngsŏngŭn myŏngnang hara: shingminji Chosŏnŭl p’agodŭn kŭndaejŏk kamjŏng ŭi t'ansaeng [Make Rebellious Kyongsong Merry: The Birth of Modern Affect Borrowed in Colonial Korea]. Seoul: Ungjin Chisik Hausu.

Sanghur Society. 2005. Pan'gongjuŭi wa Han'guk munhak [Anticommunism and Korean Literature]. Kip'ún Saem.

So-yŏn, Kim. 2003. Chŏnhu Han'guk ŭi yŏnghwa tamnon esŏ 'riŏllijŭm' ǔi ŭimie kwan hayŏ: P'iagor ŭi met'a pip'yŏng ŭl t'onghan chŏpkŭn [On 'Realism' in Postwar Korean Film Discourse: A Metacritical Approach to Piago]. In Maehok kwa hondonŭi shidae: 50 -yŏndae Han'guk yŏnghwa [The Age of Fascination and Chaos: Fifty Years of Korean Film], ed. Kim So-yŏn et al. Seoul: Sodo.

So-yŏn, Kim, et al. 2003. Maehok kwa hondonŭi shidae: 50-yŏndae Han'guk yŏnghwa [The Age of Fascination and Chaos: Fifty Years of Korean Film]. Seoul: Sodo.

Tae, Yi. 1988. Nambugun [A North Korean Partisan in South Korea]. Seoul: Ture.

Takeshi, Fuji. 2008. Che 1konghwaguk üi chibae ideollogi [The Ruling Ideologies of the First Republic: Anti-Communism and its Variants], Yoksa Pip'yŏng 83. Summer: The Institute of Korean Historical Studies.

The Institute of Counterespionage (ed.). 1972. Chigong kyoyuk tokpon [Knowing Communism Education Reader]. Seoul: Hŭkbaek munhwasa.

\section{Submit your manuscript to a SpringerOpen ${ }^{\circ}$ journal and benefit from:}

- Convenient online submission

- Rigorous peer review

- Immediate publication on acceptance

- Open access: articles freely available online

- High visibility within the field

Retaining the copyright to your article 